術前・術後合併症よりみた糖尿病重症度判定の試み

\begin{tabular}{llllll} 
能美 明夫 & 渡部 & 洋三 & 織畑 & 道宏 & \multicolumn{2}{l}{ 矢ヶ崎喜三郎 } \\
百瀬 隆二 & 石井 康裕 & 森本 & 俊雄 & 佐藤 & 浩一 \\
大久保 剛 & 佐々木 浩 & 矢吹 清隆 & 巾 & 尊宣 \\
川島 利信 & 津村 秀憲 & 近藤慶一郎 & 城所 & 仂
\end{tabular}

\title{
EVALUATION OF SEVERITY OF DIABETES MELLITUS BASED ON PREOPERATIVE AND POSTOPERATIVE COMPLICATIONS
}

\author{
Akio NOMI, Yozo WaTANaBE, Michihiro ORIHATA, \\ Kisaburo YAGASAKI, Ryuzi MOMOSE, Yasuhiro ISHII, \\ Toshio MORIMOTO, Koichi SATO, Tsuyoshi OKUBO, \\ Hiroshi SASAKI, Kiyotaka YABUKI, Takanori HABA, \\ Toshinobu KAWASHIMA, Hidenori TSUMURA, Keiichiro KONDO \\ and Tsutomu KIDOKORO
}

Fist Department of Surgery, Juntendo University School of Medicine

\begin{abstract}
著者らは, 糖尿病の外科的重症度判定を目的として, 術前に糖尿病と診断された手術症例を術前イ ンスリン投与不要群, インスリン小量投与群 (20IU/日未満, low dose : L 群) および大量投与群 (20 IU/日以上, high dose : H 群) の 3 群に分け，術前拈よび術後合併症に関して検討した，術前合併症 併存率は，インスリン投与 2 群(H群は $76.0 \%$ ，L群は $71.4 \%)$ 飞招いて, 投与不要群の併存率 $20.3 \%$ より有意に高率であった。また術後合併症発生率は，投与不要群の $11.4 \%$ と比較して，H群は $40.0 \%$ と有意の高值を示し， L 群も $22.9 \%$ と高い傾向を示した。 以上より, 術前インスリン投与不要群を軽 症，L群を中等症， H群を重症とする糖尿病の外科的重症度判定は有用であることが示唆された。
\end{abstract}

索引用語：糖尿病重症度判定, 糖尿病合併手術症例, インスリン投与不要群, インスリン小量投与群, インスリ ン大量投与群

\section{I. 緒 言}

近年, 外科領域に打ける糖尿病合併症例の増加によ り，術前・術後の栄盖を念頭においた糖尿病管理が要 求されてきている。糖尿病は, 体内においてインスリ ンの絶対的あるいは相対的な不足によってひき起こさ れ, 糖質, 蛋白質, 脂質および電解質の代謝異常を示 すが，さらにこれらの代謝異常に起因する諸臟器の障 害を合併することが多いため，手術侵襲により重篤な 合併庭がひき起こされることが少なくない．

本研究の目的は, 消化器手術症例のうち糖尿病合併

$<1986$ 年 7 月 9 日受理 $>$ 別刷請求先：能美 明夫 T113 文京区本郷 $2-1-1$ 順天堂大学医学部第 1 外科
症例を術前インスリン投与不要群と投与群（投与量に より 2 群に分類）の 3 群に分けて, 術前・術後合併症 併存率を検討し, 術前に糖尿病合併手術症例の重症度 判定を試みることにある。

\section{II. 対象と方法}

\section{1. 対象}

対象は，1965年 1 月から1984年12月までの 20 年間に 当教室に怙いて手術が施行された糖尿病合併症例183 例である.これは同時期に行われた当教室における総 手術症例 9,778 例の $1.9 \%$ に相当した。糖尿病合併症例 のらち, 術前にインスリン投与を必要とした症例は 183 例中60例 $(32.8 \%)$ であった. インスリン投与法はす べて皮下投与とし，1 日尿糖が $10 \mathrm{~g}$ 以下となるように 


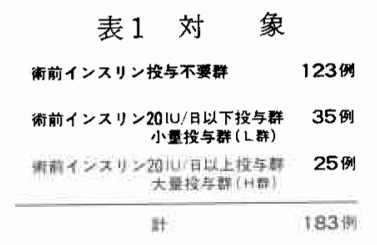

コントロールされた（表 1 ).

疾患別内訳では, 胃癌59例, 胆石症58例, 消化性潰 瘍16例, 結腸癌11例, 桠臓癌13例などであり, 男女比 は2.4：1 と男性に多く, 年龄は $36 \sim 84$ 歳, 平均 60 歳と 高齢であった。な和緊急手術例は除外した。

\section{2. 方法}

著者らは，糖尿病合併症例を術前インスリン投与不 要群と投与群とに分け，さらにインスリン投与群を投 与量が20IU/日未満の小量投与群 (low dose : L 群) と 20IU/日以上の大量投与群 (high dose : H 群) に分け, 計 3 群とした。 その内訳は，術前インスリン投与不要 群123例, インスリン投与L群35例, インスリン投与 H 群 25 例である(表 1 )。これら 3 群の術前合併症併存率 を 1 つ以上の併存率と複数の併存率に分けて検討し， さらに術後合併症発生率についても 3 群間で比較検討 した。

なお得られたデータはすべて $\chi^{2}$ 検定で統計処理を 行い, 危険率 $5 \%$ 以下を有意差ありと判定した。

\section{III. 成 績}

1. 年代別糖尿病合併症例の推移

検討期間を前期，後期の各 10 年間に分けて検討する 之, 前期 10 年間の術前糖尿病合併症例は手術症例 4,778 例中 43 例 $(0.9 \%)$ であるが, 術期 10 年間の糖尿病合併 症例は 5,000 例中 140 例 $(2.8 \%)$ と有意 $(\mathrm{p}<0.001)$ の 増加を示した。ささら術前糖尿病合併症例のらち, 術 前インスリン投与不要群，インスリン投与L群扰よび H群の 3 群について, 前期, 後期に分けて検討してみ ると, 投与不要群では前術よりも後期に虰いて糖尿病 合併症例内で占める比率が低下する傾向 $(\mathrm{p}<0.10)$ を 示したが，インスリン投与群ではし群およびH群はと もに前期に比較して後期に括いて高い比率を示した が，有意差はみとめられなかった（表 2).

2. 術前合併症

(1) 術前合併症の内訳

糖尿病症例の術前合併症の内訳について，術前イン スリン投与不要群, インスリン投与 L 群およびH群の 3 群で検討した. 各群ともに術前合併症に占める循環 器系障害の比率は高く, 各群の全合併症のなかで招の
表 2 年代別糖尿病合併症例の推移

\begin{tabular}{|c|c|c|c|c|c|}
\hline & 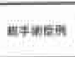 & मnesक & 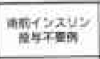 & 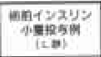 & 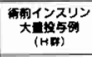 \\
\hline 5. & 4778 & $\begin{array}{c}43 \\
(0.94)\end{array}$ & $\begin{array}{l}34 / 43 \\
(75.18 i)\end{array}$ & $\begin{array}{l}6 / 43 \\
(14.0 \%)\end{array}$ & $\begin{array}{l}3 / 43 \\
(7.0 \%)\end{array}$ \\
\hline${ }_{4}=$ & 5000 & $\begin{array}{l}140 \\
(2.85)\end{array}$ & $\begin{array}{l}89 / 140 \\
(63.64)^{2}\end{array}$ & $\begin{array}{c}29 / 140 \\
(70-78)\end{array}$ & $\begin{array}{l}22 / 140 \\
(15.7 \pm 1\end{array}$ \\
\hline it & 9778 & $\begin{array}{r}183 \\
(195)\end{array}$ & $\underset{(67.2 \%)}{123 / 183}$ & $\begin{array}{l}35 / 183 \\
(19: 11)\end{array}$ & $\begin{array}{c}25 / 183 \\
(13.75)\end{array}$ \\
\hline
\end{tabular}

表 3 術前合併症の内訳

\begin{tabular}{|c|c|c|c|c|}
\hline & 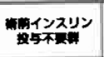 & 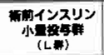 & 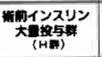 & t \\
\hline 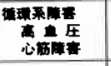 & $22 \frac{3}{3}(69.4 \%)$ & $\frac{14}{6}(54.1 \%)$ & $8_{3}^{8}(42.4 \%)$ & $12(56.5 \%)$ \\
\hline 呼吸其瘦: & $3(8.3 \%)$ & $5(13.5 \%)$ & $5(19.2 \%)$ & $13(13.1 \%)$ \\
\hline 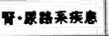 & $4(11.1 \%)$ & $3(8.1 \%)$ & $5(19.2 \%)$ & $12(12.1 \%)$ \\
\hline 眼急 & $1(2.8 \%)$ & $3(8.1 \%)$ & $2(7.7 \%)$ & $6(6.1 \%)$ \\
\hline 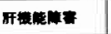 & $2(5.6 \%)$ & $2(5.4 \%)$ & 1 (3.8\%) & $5(5.1 \%)$ \\
\hline 七の他 & $1(2.8 \%)$ & $4(10.8 \%)$ & $2(7.7 \%)$ & $7(7.1 \%)$ \\
\hline it & 36 牛 (\%) & 37件 (\%) & $26 \#(\%)$ & $99 \neq(\%)$ \\
\hline
\end{tabular}

表 4 各群に括ける衍前合併症併存頻度

\begin{tabular}{|c|c|c|c|c|c|}
\hline & & 楮 & 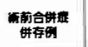 & 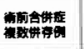 & 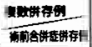 \\
\hline \multicolumn{2}{|c|}{ 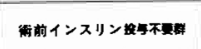 } & 123 & $\begin{array}{c}25 \\
(20.3 \%)\end{array}$ & $\begin{array}{c}8 \\
(6.5 \%)\end{array}$ & $\begin{array}{r}8 / 25 \\
(32.0 \%)\end{array}$ \\
\hline \multirow{2}{*}{$\begin{array}{c}\text { 再前インスリン } \\
\text { 投与解 }\end{array}$} & 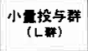 & 35 & $\begin{array}{c}25 \\
(71.4 \%)^{*}\end{array}$ & $\stackrel{9}{9}$ & $\begin{array}{r}9 / 25 \\
(36.0 \%)\end{array}$ \\
\hline & 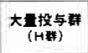 & 25 & $\begin{array}{c}19 \\
(76.0 \%)^{*}\end{array}$ & $\underset{(28.0 \%)^{7}}{7}$ & $\begin{array}{r}7 / 19 \\
(36.8 \%)\end{array}$ \\
\hline \multicolumn{2}{|l|}{ है } & 183 & $\begin{array}{c}69 \\
(37.7 \%)\end{array}$ & $\begin{array}{c}24 \\
(13.1 \%)\end{array}$ & $\begin{array}{l}24 / 69 \\
(34.8 \%)\end{array}$ \\
\hline
\end{tabular}

おの $69.4 \% ， 54.1 \% ， 42.4 \%$ を占めた。 さらに腎障害 や眼疾患などを含めると，血管障害に基づくと考えら れる合併症が各群において大部分を占めている.また, その注かの合併疾患の占める比率についてる, 各群に おいては差はみとめられなかった（表 3 ）.

（2）各群に打ける 1 つ以上の術前合併症併存頻度 糖疗病合併症例 183 例中 69 例 $(37.7 \%)$ に 1 つ上上の 術前合併症併存がみとめられた。これを 3 群に分けて 検討すると, 術前インスリン投与不要群では 123 例中 25 例 $(20.3 \%)$ ，インスリン投与 L 群では35例中25例 (71.4\%)，H群では25例中19例（76.0\%）にそれぞれ 術前合併症併存がみられ, 術前インスリン投与不要群 と比較してL群およびH群はともに有意 $(\mathrm{p}<0.001)$ の高値を示した（表 4 ）.

（3）各群に打ける複数の術前合併症併存頻度

糖尿病合併症例183例中 24 例 (13.1\%) に2つ以上の 術前合併症がみとめられ，1 1 以上の合併症併存例69 
例中 24 例 $(34.8 \%)$ を占めた。これを 3 群に分けて検 討すると, 術前インスリン投与不要群に打ける 2 つ以 上の術前合併症併存例は123例中 8 例 $(6.5 \%)$ と低率 であるが, インスリン投与 L 群では35例中 9 例 (25.7\%)，H群では25例中 7 例 $(28.0 \%)$ と高率であ りそれぞれインスリン投与不要群との間に有意差 （p<0.01）がみとめられた。しかし，各群における 1 つ以上の術前合併症併存例に対する複数併存例の占め る頻度に有意差はみとめられなかった（表 4 ）。

3. 術後合併症

（1）術後合併症の内訳

糖尿病症例に打ける術後合併症の内訳は, 腹腔内膿 瘍, 腹壁膿瘍, 肺炎, 尿路系感染など感染症が多く全 合併症の $52 \%$ を占め, 続いて縫合不全, 循環器系障害 がみられた．高浸透圧性非ケトン性昏睡といった血糖 コントロール不能の重症例はみとめられなかった。し かし, 血糖値が $500 \mathrm{mg} / \mathrm{dl}$ 以上の高值を示寸症例を術 前インスリン投与不要群扰よびL群において 1 例ずつ みとめたが、インスリン投与により，すみやかにコン トロールすることができた。な招 2 例とるに術前より intravenous hyperalimentation (以下 IVH) が施行さ れていた症例である。ささらに糖尿病症例を 3 群に分け て検討したが，インスリン投与不要群，インスリン投 与L群およびH群いずれに扔いても全合併症のうちに 感染症の占める頻度は高率であったが各群間で有意差 はみとめられず,他の合併症の頻度も同様であった(表 5 ).

（2）各群における術後合併症発生頻度

糖尿病症例183例中 32 例 (17.5\%) に術後合併症の発 生がみられ，これを 3 群に分けて検討してみると，術 前インスリン投与不要群では123例中14例 (11.4\%), インスリン投与L群では35例中 8 例 $(22.9 \%), \mathrm{H}$ 群で は25例中10例 $(40.0 \%)$ に術後合併症発生がみとめら れたが，H群はインスリン投与不要群と比較して有意 （p<0.01）に高率であり，またL群もインスリン投与 不要群と比較して合併症発生率は高値を示す傾向 (p<0.10）にあった（表 6).

（3）各群に扮忛る死亡例 (直死例) の検討

糖尿病症例183例中11例 (6.0\%) に術直死がみとめ られたが，これを 3 群に招いて検討した。術前インス リン投与不要群123例では術直死例は 4 例 $(3.3 \%)$ と 低率であったが，インスリン投与 L 群では35例中 4 例 (11.4\%)，H群では25例中 3 例 $(12.0 \%)$ と投与不要 群と比較して高率であったが, 有意差はみとめなかっ
表 5 術後合併症の内訳

\begin{tabular}{|c|c|c|c|c|}
\hline & 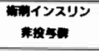 & 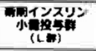 & 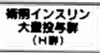 & н \\
\hline 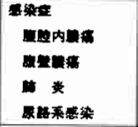 & $\begin{array}{l}2 \\
3 \\
3^{(41.7 \%)} \\
2\end{array}$ & $\begin{array}{l}3 \\
1 \\
2 \\
0\end{array}$ & $\begin{array}{l}2 \\
2 \\
1 \\
2\end{array}$ & $\begin{array}{l}10 \\
6_{(52.0 \%)} \\
6^{4}\end{array}$ \\
\hline 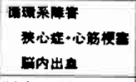 & $2^{1(12.5 \%)}$ & $0^{1}(7.6 \%)$ & $0^{2}(15.4 \%)$ & $2^{4}(12.0 \%)$ \\
\hline 铃不全 & $7(29.1 \%)$ & $4(30.8 \%)$ & $2(15.4 \%)$ & $13(26.0 \%)$ \\
\hline Ex) & $1(4.2 \%)$ & $1(7.6 \%)$ & $O(0 \%)$ & $2(4.0 \%)$ \\
\hline その化 & $3(12.5 \%)$ & $1(7.6 \%)$ & $2(15,48)$ & $6(12.0 \%)$ \\
\hline H & 24 \# (\%) & $134(\%)$ & 134 (\%) & $50 \%(\%)$ \\
\hline
\end{tabular}

表 6 各群における術後合併症発生頻度

\begin{tabular}{|c|c|c|c|}
\hline & & 帮的效 & 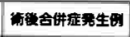 \\
\hline \multicolumn{2}{|c|}{ 需前インスリン投与不需䨛 } & 123 & $14(11.4 \%)$ \\
\hline \multirow{2}{*}{$\begin{array}{c}\text { 海的インスリン } \\
\text { 投与舴 }\end{array}$} & 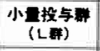 & 35 & $8(22.9 \%)^{* 2}$ \\
\hline & 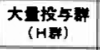 & 25 & $10(40.0 \%)^{\circ}$ \\
\hline \multicolumn{2}{|l|}{ st } & 183 & $32(17.5 \%)$ \\
\hline
\end{tabular}

表 7 各群における死亡例（直死例）の検討

\begin{tabular}{|c|c|c|c|c|c|c|c|}
\hline & & \multirow{2}{*}{ 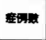 } & \multirow{2}{*}{ 无七 } & \multicolumn{4}{|c|}{$\overline{\boldsymbol{z}}$} \\
\hline & & & & 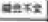 & m & DIC & asene \\
\hline \multicolumn{2}{|c|}{ 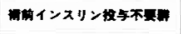 } & 123 & $4(3.3 \%)$ & 2 & $\mathbf{I}$ & $\mathbf{I}$ & \\
\hline \multirow{2}{*}{ 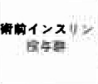 } & 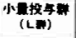 & 35 & $4(11.4 \%)$ & 3 & & & 1 \\
\hline & 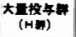 & 25 & $3(12.0 \%)$ & 1 & 1 & & 1 \\
\hline \multicolumn{2}{|l|}{ at } & 183 & $11(6.0 \%)$ & 6 & 2 & 1 & 2 \\
\hline
\end{tabular}

た、また死因は，各群ともに縫合不全を原因とする死 亡例が多かったが，インスリン投与 2 群に心筋梗塞に よる死亡各 1 例がみられた。 しかし，高浸透王性非ヶ トン性昏睡といった糖尿病のコントロール不能による 死亡例はみとめなかった（表 7).

\section{IV. 考 察}

糖尿病は，体内におけるインスリンの絶対的あるい は相対的な不足によってもたらされる.糖質, 蛋白質, 脂質扣よび電解質の代謝異常であり, 栄養代謝面での アンバランスが存在し, さらに主要臓器の機能障害を 伴うことが多い.糖尿病を有する外科症例に执いては, 手術侵糔に対する生体反応のため内分泌動態の変動を きたし、さらに手術後の栄養飢餓状態によってもたら される代謝異常などから容易に糖尿病の増悪をきた す.また, 他の主要臟器障害とあいまって, 重篤な合 併症をもたらすものと考学られる. 以上の理由から， 糖尿病を有する外科症例は poor risk として取り扱わ れることが多く, 術前に糖尿病に対する正確でかつ簡 
便な重症度判定が望まれている。

糖尿病に対する治療は，一般に内科的には食事療法 を中心に行い，中等症以上に招いて経口糖尿病薬ある いはインスリンの投与を行っているが，外科に拉いて は術前に十分な糖質を投与し，必要に応じてこれに見 合う量のインスリンを投与して，体内に扣けるグリ コーゲンの貯蔵を促しておく。一般に糖尿病症例の術 前コントロールは，成人に括いて 1 日当り $30 \sim 40 \mathrm{cal} /$ $\mathrm{kg}$ のカロリー（糖質は最低150～200g/日）を投与した 上で, 空腹時血糖100 150mg/dl, 1 日尿糖は陽性で10 $\mathrm{g} /$ 日以下，尿中ヶトン体陰性を目標とするものが多 く，著者らもこれに従っている. 今回対象とした症例 は全例術前にコントロールし党た症例が用いられた。

食生活の変化や対象年齢の高齢化などから, 外科症 例に打ける糖尿病合併例の増加が報告されている。 三 村ら ${ }^{11}$ は，1958年〜1963年の糖尿病合併症例手術例は 0.7\%であったが，1964１969年では1.4\%に増加した とし，1979年玉熊ら 2)は2.5３.0\%を占めたと報告し ている.また板東ら31は, 1976年以降 6 年間において手 術症例の $9.0 \%$ に糖尿病合併症例をみとめている. 当教 室に扣ける過去 20 年間の検討においても, 前期 10 年間 は総手術症例の $0.9 \%$ であった糖尿病合併症例が, 術後 10 年間では $2.8 \%$ と有意の増加を示した。

術前合併症は, 糖尿病症例の 40 70\%にみとめると いわれ, 血管病変, 特に動脈硬化性病変にもとつう高 血圧, 心疾患执よび腎疾患が多く，全合併症の半数以 上を占めている. 当教室に颃いても, 糖尿病症例183例 中69例 (37.7\%) 飞術前合併症併存をみとめたが，高 血压や心笳障害が全合併症の半数以上にみられ, 白内 障や糖尿病性網膜症, 腎機能障害などを加学ると, 血 管性病変と考えられる疾患が全合併症の大部分を占め た，血管病変に起因寸る疾患は，糖尿病と加龄という 2つの因子が関連するため高率に合併しやすいと玉態 ら 2 は述へでう, Shuman" 同様に, 糖尿病は硬化性 血管病変による心筋障害や腎障害を合併しやすいと報 告している.ついで術前合併症として易感染性にもと ら゙く呼吸器疾患や尿路感染症がみられるが，糖尿病に 打ける易感染性の要因として, 血液や組織内の糖の増 加が細菌の繁殖を促すこと, 抗体産生能の低下, 白血 球貫食能低下, 糖尿病による二次的循環障害, 副腎機 能え進などが考学られている，著者らの成績では，こ れらの術前合併症併存率はインスリン投与不要群では 低率であったが，インスリン投与 2 群では投与不要群 と比較して有意に高率であった。
糖尿病を合併する外科症例では，手術侵襲による生 体反応として, catecholamine, cortisol, growth hormoneなどのいわゆる insulin antagonist hormone 分 泌が促進されることに加え, 術後の栄養飢餓状態のた めに, 術前より存在する代謝障害の増悪をきたす。し たがって, 糖疗病症例では術前合併症の存在あるいは 潜在する臓器障害のため, 非糖尿病症例と比較して高 率に術後合併症が発生すると考光られる。諸家の報 告5)8 では, 糖尿病症例の $20 \sim 40 \%$ 亿術後合併をみとめ たとしてあるが，当教室では糖尿病症例183例中 32 例 (17.5\%)に術後合併症をみとめた。術後合併症として は，感染症を中心とする報告が多(576)が，当教室にお いても感染症が術後合併症の約半数を占めた。また近 年血管病変に起因する虚血性心疾患や脳血管障害など の合併症患の増加が報告されている。ささらに，術後に 高血糖をきたし，血糖コントロール不能から高浸透圧 性非ケトン性昏睡となり，重篤な転慢をたどることが 知られている. 特に, 近年 IVH の導入により，以前は 栄養状態不良のため手術不能とされた症例に対しても 積極的に外科手術が行われるようになってきており， 術後も早期より高カロリ一投与が関始されるため, 術 後高血糖を呈する症例が増えていると考光られる。 のため, 術後頻回のチェックによる適切なカロリーお よび水分，電解質の投与が必要とされている．当教室 においても，術後に一過性の高血糖 $(500 \mathrm{mg} / \mathrm{dl}$ 以上) を呈する症例を経験したが，適切なインスリン投与に より，すべてコントロールすることができた，当教室 における術後合併疾患の内訳は，インスリン投与不要 群および投与 2 群の 3 群ともに同様の傾向を示し, 各 群間に有意差はみとめられなかった。しかし，術後合 併症の発生頻度はインスリン投与不要群, インスリン 投与 $\mathrm{L}$ 群，H群の順に高くなり，H群はインスリン投 与不要群との間に有意差がみとめられた。

外科症例に和ける併存糖疗病の重症度判定の試みは 以前よりなされている。しかし，その汪とんどは糖負 荷試験にもとづく分類が用いられており, 外科的特徵 を重視した判定法は多くの問題を抱支ているため,い まだ確立するにいたっていない.玉熊ら゙は, 糖尿病症 例の空腹時血糖值および耐糖能試験 (glucose tolerance test : 以下 GTT) の最高血糖值より糖尿病の重症度 を 3 つに分類した. 出口ら ${ }^{8}$ は玉態の分類にしたがっ て, 術前糖尿病重症度と合併症併存率について検討し， 重症度と相関して合併症併存率が高くなることを報告 している. また佐藤ら 
たがい耐糖能試験より糖尿病症例を分類し, 重症糖尿 病とした症例の術前・術後合併症併存率が他の群より む高いことを示した，著者らは，糖尿病合併症例を術 前インスリン投与の有無とその投与量により, 術前イ ンスリン投与不要群, インスリン投与 L群およびイン スリン投与 $\mathrm{H}$ 群の 3 群に分類し, 各群の術前・術後合 併症に関して検討を加壳ることにより，糖尿病の外科 的重症度判定を試みた。術前・術後合併症の併存は之 ๖にインスリン投与不要群, インスリン投与 $\mathrm{L}$ 群, 投 与 H群の順で高率であり, 特に投与不要群とL群扣よ びH群との間に術前合併症併存率に関して有意差をみ とめたほか，術後合併症発生率に関して子投与不要群 と H群との間に有意差をみとめた。また H群の術前お よび術後合併症併存率は，L群よりも有意差はみられ なかったが高率であった。したがって，インスリン投 与の有無扰よび投与量の差による糖尿病合併外科症例 の重症度判定の有用性が示唆され，インスリン投与不 要群は軽症, インスリン投与 $\mathrm{L}$ 群は中等症, インスリ ン投与 $\mathrm{H}$ 群は重症と判定しらるるのと考えられる.

\section{V. 結 語}

今回著者らは，術前に糖尿病之診断された手術症例 の糖尿病重症度判定を目的として, 糖尿病症例を術前 インスリン投与不要群, インスリン小量投与群, イン スリン大量投与群の 3 群に分けて, 術前および術後合 併症に関して検討を加光, 以下の結果を得た。

（1）当教室における過去20年間の手術症例の糖尿病 合併症例は増加傾向を示し, 前期の 10 年は手術症例の $0.9 \%$ であっが, 後期の 10 年間は $2.8 \%$ と前期と比較 して有意 $(\mathrm{p}<0.001)$ に高率であり, 同時に術前イン スリン投与を必要とした症例も有意差はなかったが増 加をみとめた。

（2）術前合併症併存率は 1 つ以上あるいは複数併存 率において，インスリン投与不要群はインスリン投与 の 2 群に比較して有意（おの扔の $\mathrm{p}<0.001, \mathrm{p}<0.01$ )
に低率であった。

（3）術後合併症発生率は，インスリン大量投与群で 最も高率であり, インスリン小量投与群, インスリン 投与不要群の順に低率となっており, 大量投与群と投 与不要群との間に有意差 $(\mathrm{p}<0.01)$ がみとめられたほ か, 小量投与群の発生率は投与不要群上りも高い傾向 （p<0.10）がみとめられた。

(4) 手術死亡率はインスリン投与不要群では $3.3 \%$ であったが，インスリン小量投与群は $11.4 \%$ ，インス リン大量投与群は $12.0 \%$ と高率であった。

以上の結果より，外科症例に和ける糖尿病合併例の 重症度判定として, 術前インスリン投与不要群は軽症, インスリン小量投与群は中等症, インスリン大量投与 群は重症と分類しらるものと考光られる。

\section{文献}

1）三村 孝, 丸田守人, 小平 進任か: 糖尿病と外科 一剖検例および臨床例における統計的観察一. 手 術 $25: 743-749,1971$

2) 玉熊正悦, 望月英隆 : 糖尿病患者の手術をめぐる 問題. 医のあゆみ $113: 798-804,1980$

3）板東隆文, 豊島 宏, 渡辺昇汸加: 糖尿病患者 146例の術後合併症の検討。日臨外医会誌 44 ： 331-334, 1983

4) Shuman CR: Management of diabetes mellitus in patients undergoing surgery. JAMA $155: 621-626,1954$

5）佐藤寿雄, 斉藤洋一, 本田毅彦ほか：合併症のある 糖尿病患者の治療一糖尿病患者に打ける手術後の 管理一。診断々治療 $61: 1838-1844,1973$

6）川崎勝弘, 小川嘉举, 東山聖彦ほか：術後重症合併 症例に対する高かロリ一輸夜とインスリン使用例 の検討. 外科と代謝 - 栄 $15: 322-327,1981$

7）玉熊正悦，佐藤長夫，鈴木宏彰：桾尿病患者の術前 術後管理. 手術 $25: 733-742,1971$

8）出口久次, 龍礼之助, 北原信三ほか：糖氺病合併症 例の手術治療の問題点. 日臨外医会誌 $44: 327$ $-331,1983$ 